\title{
Utilization of Magnesium Hydroxide Produced by Magnesia Hydration as Fire Retardant for Nylon 6-6,6
}

\author{
Sônia D.F. Rocha \\ Departamento de Engenharia Química, UFMG
}

\author{
Virgínia S.T. Ciminelli \\ Departamento de Engenharia Metalúrgica e de Materiais, UFMG
}

\begin{abstract}
The present work investigates the use of magnesium hydroxide, produced by magnesia hydration, as a fire retardant in polymers. The hydration was carried out in an autoclave, at temperature of $130^{\circ} \mathrm{C}$ for 1 hour, and the product was further submitted to cominution in a jet mill. The solids were characterized with regard to their chemical composition, particle size distribution, surface area and morphology. The performance evaluation of the hydroxide as a flame retardant for a copolymer of nylon 6-6,6 was carried out according to the UL94 specifications for vertical burning tests. V-0 flammability rating at $1.6 \mathrm{~mm}(60 \%$ magnesium hydroxide-filled nylon composite) and at $3.2 \mathrm{~mm}$ (40\% magnesium hydroxide filled nylon composite) were achieved. Mechanical properties were maintained at the desired values. These results indicate that the hydroxide obtained from magnesia hydration can be successfully employed as a fire retardant for nylon 6-6,6.
\end{abstract}

Keywords: Fire retardant, magnesium hydroxide, nylon 6-6,6.

\section{Introduction}

The use of rubber and plastic materials in the manufacture of domestic and industrial products has grown substantially in the last decades. Some applications of these products require the utilization of flame retardants, the halogenated (bromides and chlorides) and phosphorous compounds being the most widely used ${ }^{[1,2]}$. Nevertheless, these compounds generate toxic and highly corrosive fumes in fire, which make the damage even higher. Interest in using metal hydroxides as fire retardants has grown, since these compounds do not produce fumes and present low corrosiveness ${ }^{[3-5]}$. Metal hydroxides retard combustion by absorbing heat and by cooling the substrate through dehydration reaction ${ }^{[5-7]}$.

The metal hydroxide most commonly used as a fire retardant is aluminum hydroxide. Aluminum hydroxide has been used as a fire retardant in many materials including thermosets, elastomers and thermoplastics. However, its low temperature of decomposition (approximately $180^{\circ} \mathrm{C}$ ) limits its application. Many polymers must be processed at higher temperatures, which hinders the utilization of this compound. It is exactly in these cases that the use of magnesium hydroxide becomes attractive, owing to its higher temperature of decomposition (approximately $330^{\circ} \mathrm{C}$ ). The main applications of magnesium hydroxide are in polymers such as polypropylene and nylon, which should be processed at high temperatures, and in elastomeric cable coatings, which require high temperatures for rapid processing ${ }^{[8]}$.

Magnesium hydroxide, as well as alumina trihydrate, is commonly used at high concentrations, such as $40 \%$ to $70 \%$. Due to cost considerations, magnesium hydroxide does not fully replace aluminum hydroxide. Rather, it broadens the utilization of metal hydroxides as flame retardants in a way that the damages as well as the environmental pollution are minimized.

Magnesium hydroxide-based products are available in the market. These are mainly obtained by precipitation of magnesium hydroxide from brines

Autor para correspondência: Sônia D. F. Rocha, Departamento de Engenharia Química, UFMG, Rua Espírito Santo, 35 - 6º andar,Belo Horizonte, MG, CEP:30160-030.E-mail:sdrocha@deq.ufmg.br 
and sea water ${ }^{[3]}$. The production of the hydroxide for fire retardant filler application via hydration of magnesium oxide has been hindered by the process economics. Purity requirements for this application result in the need for purification steps, which substantially increase the final cost of the product. Direct hydration becomes a very interesting option where large deposits of pure magnesite (a precursor of magnesium oxide) are available, as in Brazil ${ }^{[9,10]}$.

Different processes lead to products with different crystallite size, surface area, particle morphology and chemical composition. According to the literature ${ }^{[10]}$, these properties affect not only the fire retardant performance but also the mechanical properties of the final composite.

The present work is part of an investigation aimed at establishing the mechanism of magnesia hydration and at evaluating the use of magnesium hydroxide as a fire retardant for polymers. The utilization of magnesium hydroxide, produced by magnesia hydration, as a fire retardant for nylon $6-6,6$, is evaluated. The performance of the filler obtained by $\mathrm{MgO}$ hydration is compared with that of a commercial product obtained by precipitation from brine.

\section{Experimental}

High-grade magnesium oxide (97\%) supplied by Magnesita S.A was hydrated in a Parr autoclave (2000 $\mathrm{cm}^{3}$ ), at $130^{\circ} \mathrm{C}$, during 1 hour. After drying, the solids were milled in a jet mill and were characterized with regard to their chemical composition (X-ray fluorescence in X-ray Spectrometer Phillips PW 1600), particle size distribution (Sedigraph 5000ET), surface area (BET in Quantachrome Nova 1000), density (Quantachrome Stereopicnometer), presence of crystalline phases (Diffratometer Phillips PW 1400) and morphology (Scanning Electron Microscope - Jeol JSM 35C). Thermogravimetric (TGA) and thermodifferential (DTA) analyses determined the decomposition temperatures and the dehydration heat, respectively, in $\mathrm{N}_{2}$ atmosphere, at a heating rate of $20^{\circ} \mathrm{C} / \mathrm{min}$ (Shimadzu 50 Thermocalorimeter).

The copolymer of nylon 6-6,6, additives (lubricant and pigment) and the magnesium hydroxide were mixed at $255^{\circ} \mathrm{C}$ in a Werner \& Pfleiderer twin-screw extruder, model ZSK 30 of $30 \mathrm{~mm}$ diameter. The mixes were prepared according to the formulations shown in Table 1. The magnesium hydroxide produced by hydration
Table 1. Mix formulations using products obtained by magnesia hydration $(\mathrm{MH}-\mathrm{H})$ and precipitation (MH-P).

\begin{tabular}{|c|c|c|c|}
\hline Run ${ }^{a}$ & $\begin{array}{c}\text { Magnesium } \\
\text { hydroxide } \\
\text { (g/kg mix) }\end{array}$ & $\begin{array}{c}\text { Nylon 6-6,6 } \\
\text { (g/kg mix) }\end{array}$ & Lubricant \\
\hline 1(MH-P) & 400 & 600 & - \\
\hline 2(MH-P) & 400 & 600 & $\begin{array}{c}2 \mathrm{~g} / \mathrm{kg} \text { mix of } \\
\text { stearic acid }\end{array}$ \\
\hline 3(MH-P) & 600 & 400 & $\begin{array}{l}2 \mathrm{~g} / \mathrm{kg} \text { mix of } \\
\text { stearic acid }\end{array}$ \\
\hline $4(\mathrm{MH}-\mathrm{H})$ & 400 & 600 & - \\
\hline $5(\mathrm{MH}-\mathrm{H})$ & 500 & 500 & - \\
\hline $6(\mathrm{MH}-\mathrm{H})$ & 600 & 400 & - \\
\hline $7(\mathrm{MH}-\mathrm{H})$ & 400 & 600 & $\begin{array}{l}2 \mathrm{~g} / \mathrm{kg} \text { mix of } \\
\text { stearic acid }\end{array}$ \\
\hline $8(\mathrm{MH}-\mathrm{H})$ & 400 & 600 & $\begin{array}{l}1 \mathrm{~g} / \mathrm{kg} \text { mix of } \\
1: 1 \text { mixture of } \\
\text { zinc stearate } \\
\text { and teflon }\end{array}$ \\
\hline
\end{tabular}

${ }^{\mathrm{a}} 15 \mathrm{~g} / \mathrm{kg}$ mix of $25 \% \mathrm{w} / \mathrm{w}$ mixture of carbon black in polyamide 6 was used as pigment.

will be further referred to as $\mathrm{MH}-\mathrm{H}$ and the product of precipitation will be denominated MH-P. Sheets of 0.6 , 1.8 and $3.2 \mathrm{~mm}$ thickness were molded at $248^{\circ} \mathrm{C}$ and at an injection pressure of $35 \mathrm{Bar}$, in a Battenfeld Ferbate injector. Flaming tests were carried out according to UL94 specifications for vertical burning test ${ }^{[11]}$. Tensile strength, elongation at break and impact strength according to ISO/179/1d (Charpy - unnotched sample) and ISO 180/3A (notched sample- IZOD) were determined. The mechanical properties of the composites obtained with both magnesium hydroxides are compared with those of a polyamide 6,6 filled with $40 \%$ talc.

\section{Results and Discussion}

The chemical and physical characteristics of magnesium hydroxide fillers are shown in Table 2. The $\mathrm{MgO}$ contents in both samples are very similar. Among the minor constituents, the main differences are shown by iron and manganese oxides, with a relatively higher content in the material produced by hydration. This material is also characterized by larger particle sizes and smaller specific surface areas than the solids produced by precipitation. According to Levesque ${ }^{[12]}$, surface areas lower than $20 \mathrm{~m}^{2} / \mathrm{g}$, low reactivity with acid groups, high purity and $100 \%$ of the particle sizes below $10 \mu \mathrm{m}$ are the requirements for a good performance in polyolefins. Similar specifications are required for application 
Table 2. Chemical and physical properties of magnesium hydroxides obtained by hydration (MH-H) and precipitation (MH-P)

\begin{tabular}{ccc}
\hline Parameter & \multicolumn{2}{c}{ Content (\%) } \\
\cline { 2 - 3 } & MH-H & MH-P \\
\hline $\mathrm{MgO}$ & 68.8 & 67.8 \\
$\mathrm{CaO}$ & 0.5 & 0.7 \\
$\mathrm{SiO}_{2}$ & 0.2 & 0.2 \\
$\mathrm{Fe}_{2} \mathrm{O}_{3}$ & 0.2 & 0.1 \\
$\mathrm{Al}_{2} \mathrm{O}_{3}$ & 0.2 & 0.2 \\
$\mathrm{MnO}$ & 0.1 & - \\
Loss by ignition $($ weight \%) & 30.0 & 31.0 \\
Specific surface area, $\mathrm{BET},\left(\mathrm{m}^{2} / \mathrm{g}\right)$ & 8.6 & 18.0 \\
Median particle size,$\mu \mathrm{m}$ & 5.0 & 1.2 \\
Specific gravity, $\left(\mathrm{g} / \mathrm{cm}^{3}\right)$ & 2.44 & 2.43 \\
\hline
\end{tabular}

a $50 \%$ finer as measured by Sedigraph

of magnesium hydroxide in polyamides ${ }^{[2]}$. Figure 1 depicts the particle size distribution curves for both products. It is observed that only $92 \%$ and $88 \%$ of $\mathrm{MH}-\mathrm{P}$ and $\mathrm{MH}-\mathrm{H}$ particles, respectively, are smaller than $10 \mu \mathrm{m}$ and thus, both materials do not fully comply with the reported specifications. Examination under SEM (Figure 2) showed that the MH-H particles were constituted by aggregates of irregular and tiny crystals. The predominant crystalline phase in both $\mathrm{MH}-\mathrm{H}$ and $\mathrm{MH}-\mathrm{P}$ is $\mathrm{Mg}(\mathrm{OH})_{2}$; small amounts of $\mathrm{MgO}$ were detected in $\mathrm{MH}-\mathrm{H}$ due to the fact that hydration was not $100 \%$ complete $(\mathrm{MH}-\mathrm{H}$ loss of ignition=30.0\%).

According to the thermogravimetric analysis, $\mathrm{MH}-\mathrm{H}$ dehydration begins at $330^{\circ} \mathrm{C}$ while $\mathrm{MH}-\mathrm{P}$ dehydrates at $325^{\circ} \mathrm{C}$. Endothermic heats of $1.00 \mathrm{~kJ} / \mathrm{g}$ for $\mathrm{MH}-\mathrm{H}$ and $1.04 \mathrm{~kJ} / \mathrm{g}$ for $\mathrm{MH}-\mathrm{P}$ were measured.

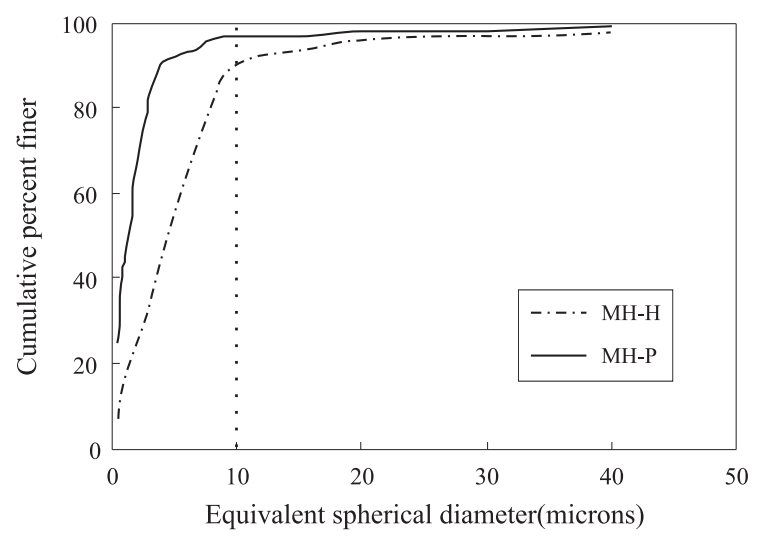

Figure 1. Particle size distribution of fillers - magnesium hydroxide obtained by hydration (MH-H) and precipitation (MH-P).

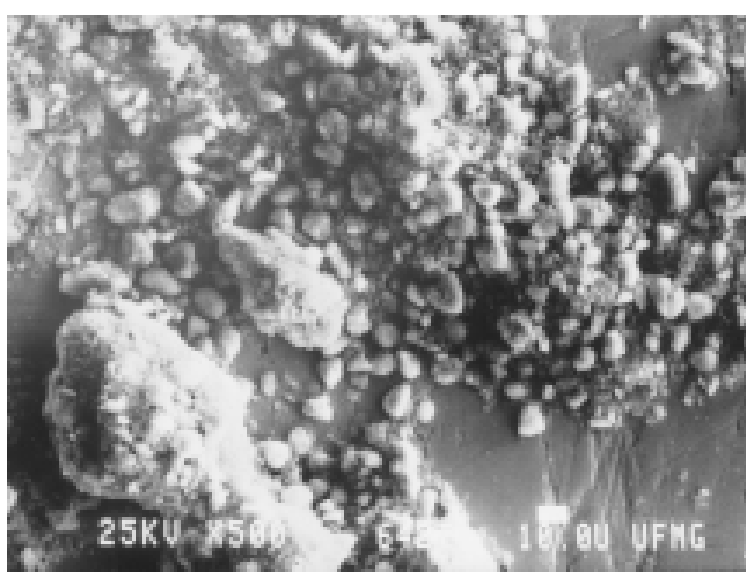

(a)

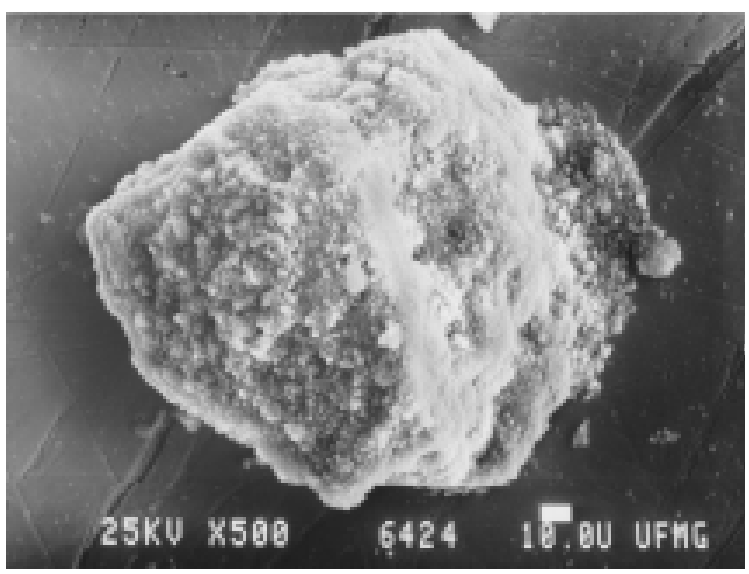

(b)

Figure 2. SEM Micrographs of fillers - magnesium hydroxide obtained by (a) hydration (MH-H) and (b) precipitation (MH-P).

Hornsby and Wang ${ }^{[2]}$ studied the application of magnesium hydroxide of various origins as fire retardant in polyamide 6 and polyamide 6,6 . The authors observed that the decomposition temperatures and also the magnitude of the endotherm peaks could be markedly affected by the experimental conditions employed during the analysis. This fact could explain the low value of the heat decomposition observed in the present work when compared to the reported value of about $1.4 \mathrm{~kJ} / \mathrm{g}$.

The results of the flammability tests are shown in Table 3. A material classed $94 \mathrm{~V}-0$ shall ${ }^{[11]}$ :

i) Not have any specimens that burn with flaming combustion for more than 10 seconds after either application of the test flame;

ii) Not have a total flaming combustion time exceeding 50 seconds for the 10 flame application for each set of five specimens;

iii) Not have any specimens that burn with flaming 
Table 3. Flammability rating of nylon 6-6,6 copolymer containing magnesium hydroxides obtained by hydration $(\mathrm{MH}-\mathrm{H})$ and precipitation $(\mathrm{MH}-\mathrm{P})$ as fillers.

\begin{tabular}{|c|c|c|c|c|}
\hline \multirow[b]{2}{*}{ Run } & \multirow[b]{2}{*}{$\begin{array}{c}\text { Final } \\
\text { composite }\end{array}$} & \multicolumn{3}{|c|}{ Flammability - UL94a } \\
\hline & & $0.8 \mathrm{~mm}$ & $1.6 \mathrm{~mm}$ & $3.2 \mathrm{~mm}$ \\
\hline 2 & $\begin{array}{l}40 \% \text { MH-P } \\
+ \text { stearic } \\
\text { acid }\end{array}$ & $\mathrm{V}-2 / \mathrm{V}-2$ & $\mathrm{~V}-2 / \mathrm{V}-2$ & $\mathrm{~V}-0 / \mathrm{V}-0$ \\
\hline 3 & $\begin{array}{l}60 \% \text { MH-P } \\
+ \text { stearic } \\
\text { acid }\end{array}$ & - & V-0/V-0 & - \\
\hline 4 & $40 \%$ MH-H & $\mathrm{V}-2 / \mathrm{V}-2$ & $\mathrm{~V}-2 / \mathrm{V}-2$ & - \\
\hline 6 & $\begin{array}{l}60 \% \mathrm{MH}-\mathrm{H} \\
+ \text { stearic } \\
\text { acid }\end{array}$ & - & $\mathrm{V}-0 / \mathrm{V}-0^{\mathrm{b}}$ & - \\
\hline 7 & $\begin{array}{l}40 \% \mathrm{MH}-\mathrm{H} \\
+ \text { stearic } \\
\text { acid }\end{array}$ & $\mathrm{V}-2 / \mathrm{V}-2$ & $\mathrm{~V}-2 / \mathrm{V}-0$ & $\mathrm{~V}-0 / \mathrm{V}-0^{\mathrm{b}}$ \\
\hline 8 & $\begin{array}{l}40 \% \mathrm{MH}-\mathrm{H} \\
+ \text { zinc } \\
\text { stearate and } \\
\text { teflon }\end{array}$ & $\mathrm{V}-2 / \mathrm{V}-2$ & $\mathrm{~V}-2 / \mathrm{V}-2$ & - \\
\hline
\end{tabular}

${ }^{\mathrm{a}} 48 \mathrm{~h}$ conditioning at $23 \pm 2^{\circ} \mathrm{C}$ and $50 \pm 5 \%$ relative humidity/ after $168 \mathrm{~h}$ at $70 \pm 1^{\circ} \mathrm{C}$

${ }^{\mathrm{b}}$ without conditioning.

or glowing combustion up to the holding clamp;

iv) Not have any specimens that drip flaming particles that ignite the dry absorbent surgical cotton located $305 \mathrm{~mm}$ below the test specimen;

v) Not have specimens with glowing combustion that persists for more than 30 seconds after the second removal of the test flame.
The requirements that must be reached by a material classed as $94 \mathrm{~V}-1$ and $94-\mathrm{V}-2$ are less restrictive.

The results indicate $\mathrm{V}-2$ flammability rating at 0.8 and $1.6 \mathrm{~mm}$ for $40 \%$ magnesium hydroxide (MH-H) filled nylon composite, in the presence and absence of the additives. Better flammability rating ( $\mathrm{V}-0)$ either at $1.6 \mathrm{~mm}(60 \% \mathrm{MH}-\mathrm{H})$ and at $3.2 \mathrm{~mm}(40 \%$ $\mathrm{MH}-\mathrm{H})$ was achieved. Hornsby et $\mathrm{al}^{[13]}$ obtained V-0 flammability rating at $3.0 \mathrm{~mm}$ for $60 \%$ magnesium hydroxide-filled nylon 6 composite. In the present work, V-0 flammability rating at $1.6 \mathrm{~mm}$ was also reached for $60 \%$ magnesium-hydroxide-filled nylon 6-6,6 composite. Similar results were obtained using the product (MH-P) produced from magnesium hydroxide precipitation from brine. According to Hornsby et alli ${ }^{[13]}$, the origin of the product may strongly influence the flammability characteristics of polyamide 6 and polyamide 6,6 . Despite the different origins, particle sizes and surface areas of the fillers used in the present study, no significant differences in flammability rating were observed.

The final compounds obtained with both fillers (MH-H and MH-P) presented similar mechanical properties (Table 4). The properties of a polyamide filled with $40 \%$ talc are also included ${ }^{[14]}$. The impact strength (unnotched charpy) was higher when the both magnesium hydroxides (MH-H and MH-P) associated with stearic acid were used. Despite the fact that a high percentage of filler leads to better flammability class, the mechanical properties were affected in a deleterious manner by an increase in the magnesium hydroxide dosage. The increase in the magnesium hydroxide

Table 4. Mechanical properties of nylon 6-6,6 copolymer filled with magnesium hydroxide obtained by hydration (MH-H) and precipitation (MH-P).

\begin{tabular}{|c|c|c|c|c|c|}
\hline Run & Composite & $\begin{array}{c}\text { Tensile strength } \\
\text { (MPa) }\end{array}$ & $\begin{array}{c}\text { Elongation at break } \\
\qquad(\%)\end{array}$ & $\begin{array}{c}\text { Impact strength (Charpy } \\
\text { - unnotched sample) } \\
\mathbf{k J} / \mathbf{m}^{2}\end{array}$ & $\begin{array}{c}\text { Impact strength (Izod } \\
\text { - notched sample) } \\
\mathbf{k J} / \mathbf{m}^{2}\end{array}$ \\
\hline - & $\begin{array}{l}\text { Poliamide } 6,6 \\
\text { with } 40 \% \text { talc }^{[12]}\end{array}$ & 86 & 4 & 23 & - \\
\hline 2 & $\begin{array}{l}40 \% \mathrm{MH}-\mathrm{P}+ \\
\text { stearic acid }\end{array}$ & 68,9 & 2,98 & 43,2 & 2,9 \\
\hline 4 & $40 \% \mathrm{MH}-\mathrm{H}$ & 78,0 & 2,80 & 23,0 & 3,0 \\
\hline 5 & $50 \% \mathrm{MH}-\mathrm{H}$ & 78,0 & 1,70 & 20,0 & 3,0 \\
\hline 7 & $\begin{array}{l}40 \% \mathrm{MH}-\mathrm{H}+ \\
\text { stearic acid }\end{array}$ & 66,9 & 2,84 & 50,1 & 2,9 \\
\hline
\end{tabular}


concentration from $40 \%$ to $50 \%$ led to a composite with a lower impact strength (unnotched Charpy) and the elongation at break was reduced in $40 \%$, far below the desired value of $4 \%$. The utilization of stearic acid as a lubricant led to a higher elongation at break and a higher impact strength. However, a material with lower tensile strength was obtained. The impact strength (Izod -notched sample) was not altered by the presence of this additive. A comparison between the mechanical properties of the final composite and the values which are specified by polyamides producers for a polymer containing $40 \%$ of mineral filler (talc) ${ }^{[14]}$ indicates that formulations are still not optimized. It is important to mention that it was beyond the scope of this study to optimize the formulations, and also to evaluate other additives such as silanes, which could improve the flammability ratings as well as the mechanical properties of the final composite. These results demonstrate the potential application of magnesium hydroxide obtained by magnesia hydration as fire retardant for a copolymer of nylon 6,6-6.

\section{Conclusions}

The potential utilization of magnesium hydroxide obtained by magnesia hydration as a fire retardant in a copolymer of polyamide 6-6,6 was demonstrated, since the flammability ratings as well as the mechanical properties require in many industrial applications were achieved. Despite the different origin, the performance of the material produced by hydration of $\mathrm{MgO}$ was similar to that obtained by a commercial product through precipitation of the hydroxide from brine.

\section{Acknowledgements}

The authors would like to thank CAPES, CNPq, Rhodia S.A and Magnesita S.A. and, especially, Cláudio Barros and Renato Ciminelli for their important contributions.

\section{References}

1. Lawson, D.F.- Rubber Chem. Technol., 59, p.455 (1986).
2. Hornsby, P. R \& Wang, J. - Prog. Rubber Plastics and Technol., 10 (3), p.204 (1994).

3. Rothon, R. N. -"Production of Carbonates and Hydrates and Their Use as Flame Retardant Fillers", in: Proceedings of the EUROFILLERS-95, p.73, Mulhouse -France, (1995).

4. Holloway, L. R. - Rubber Chem Technol., 61, p.186 (1987).

5. Sobolev, I. \& Woycheshin, E. A. - "Alumina Trihydrate", in: Handbook of Fillers for Plastics, chap.6, Katz, H.S. \& Milewsky, J.(ed), (1987).

6. Lawson, D. F.; Kay, E. L. \& Roberts Jr., D.T. - Rubber Chemistry and Technology, 48, p.124 (1974).

7. Sherman, L. - Plastics Technol., July, 56 (1992).

8. Ashley, R. J. \& Rothon, R. N. - "Use of magnesium hydroxide as a flame retardant filler" in: Proceedings of the Mineral and Organic Functional Fillers in Polymers - International Symposium Moffis, p.87, Le Mans, (1991).

9. Coope, B. M. - Industrial Minerals, August, p.57 (1983).

10. Kessler, C. - "Outlook for magnesia products”, in: Conference Report of the Industrial Minerals'97, Toronto-Canada, (1997).

11. UNDERWRITERS LABORATORIES INC. Tests for flammability of plastics materials - UL94, $3^{\text {rd }}$.ed (1989).

12. Levesque, J. - "Magnesium-based fillers as flame retardant / smoke suppressant. Recent advances in flame retardancy of polymeric materials". Business Communications Company, Stamford, Connecticut, USA, Morton International Corp., 103 (1990).

13. Hornsby,P. R.; Jackson, V. V.; Rothon, R. N, \& Wang, J. - "Use of magnesium hydroxide as a flame retardant in polyamides", in: Proceedings of the Mineral and Organic Functional Fillers in Polymers-International Symposium Moffis-93; p.161, Namur-Belgium, (1993).

14. Rhodia - Technyl- propriedades das principais formulações- APE/CT 002, versão 002, Abril 1995.

Recebido: $28 / 06 / 01$

Aprovado: 27/09/01 